\title{
Characterisation of the multi-junction solar cell with dish-style
}

\section{photovoltaic concentration system}

\author{
Zilong Wang ,Huajie Huang, Hua Zhang, Yankun Wang, Yankang Chen and Siyue Tang \\ School of Energy and Power Engineering, University of Shanghai for Science and Technology, \\ Shanghai, 200093, PR China
}

\begin{abstract}
Keywords: concentrating photovoltaic system, triple-junction solar cell, solar, dish-style.
\end{abstract}
\begin{abstract}
A paraboloidal concentrator with homogenizer was developed for a three-junction GaP/InGaAs/Ge solar cell. The concentration ratio of this system was $200 \mathrm{X}$ and the photovoltaic cell was cooled by heat pipe. According to the experiment result, when the average direct solar radiation and the ambient temperature was $600 \mathrm{~W} / \mathrm{m}^{2}$ and $28.9^{\circ} \mathrm{C}$ respectively, the average peak output power was $2.07 \mathrm{~W} / \mathrm{cm} 2$, the average open circuit voltage was $2.72 \mathrm{~V}$, the average short circuit current was $0.65 \mathrm{~A}$, the average efficiency was $26 \%$ and the average working temperature was $63.5^{\circ} \mathrm{C}$. The influencing factors of the $\mathrm{GaP} / \mathrm{In} G a A s / G e$ triple-junction solar cell electrical properties mainly include direct solar radiation and solar cell temperature. The research results which were collected in this experiment would be applied to analyze and discuss the influence of relevant parameters on the performance of high concentration photovoltaic system.
\end{abstract}

1. Introduction

Nowadays, using solar power has become a subject of far-reaching significance which has got global attention. Solar photovoltaic power generation gets much attention in the use of solar energy. Due to the high cost of the crystalline silicon, the solar cell can't fully enter the market[1]. In order to further reduce the cost of photovoltaic power generation, concentrating technique is used to decrease the consumption of the solar cell chip, which is that the cheap concentrating system converges sunlight to a small high efficient solar cell so that it can greatly reduce the cost of the system[2 3]. The theoretical estimation shows that the cost of the concentrating photovoltaic power generation can achieve the acceptable price range for large scale application[4]. Researches of the concentrating photovoltaic system have been carried out by many researchers. M. Hein et al. using GsAs cell, established a high concentrating photovoltaic system (300X) using the way of one-dimensional tracking and secondary concentrating based on CPC concentrator. The cell efficiency is $26 \%$ at $200 \mathrm{X}$ concentrating ratio[5]. Y. Kemmoku et al., using a GaP/InGaAs/Ge triple-junction solar cell, established a high concentrating photovoltaic system by using the two-dimensional tracking mode. The concentrator is Fresnel lens and the concentrating ratio is $300 \mathrm{X}$. The daily average efficiency of the system is $17.6 \%[6]$. Yongfeng $\mathrm{Xu}$ et al. analyzed the output characteristics and output power influence factors of crystalline silicon cell array and GaAs cell array under concentration based on trough concentrating cogeneration system. Results show that the Output performance of GaAs cell array is better than that of crystalline silicon cell array under concentrating light intensity[7]. Zhilong $\mathrm{Xu}$ et al. established a dish-style concentrating photovoltaic system. The theoretical concentrating ratio is 5.7 and the actual concentrating ratio is 4.56[8]. Bin $\mathrm{Du}$ et al. established a dish-style concentrating photovoltaic system, the theoretical and actual concentrating ratio of which were respectively 5.7 and 3.18. Polycrystalline silicon solar cell was used in the system and the daily generating capacity was $1.75 \mathrm{kWh}[9]$. The theoretical concentrating ratio of the multi-mirror concentrating solar photovoltaic system set up by Haiyan Zhang et al., the output power of the solar module is $0.618 \mathrm{kWh}[10]$. 
Compared with researches abroad, there are few researches about the electrical characteristics of a photovoltaic cell, especially about the electrical characteristics of GaP/InGaAs/Ge triple-junction photovoltaic cell under high concentration. Experimental researches on the output electrical characteristic and influence factors of triple-junction solar cell under high concentration had been done based on the dish-style concentrating photovoltaic system which had simple structure, high tracking precision and convenient maintenance. The related data were collected, which would provide the experience for the further development of this type of photovoltaic power generation system.

2. Experimental system

The experimental system included a high concentration system, a sun tracking system, a multi-junction solar cell, and a heat-pipe based cooling system, as showed in Fig 1. The experiments were conducted on a $0.5 \times 0.5 \mathrm{~cm}^{2}$ triple-junction InGaP/InGaAs/Ge solar cell which was manufactured by Shenzhen Yin Xuan Sheng Technology Co., Ltd, as shown in Fig 2. The advantages of this solar cell were better light absorption coefficient, smaller temperature coefficient and higher efficiency and so on.

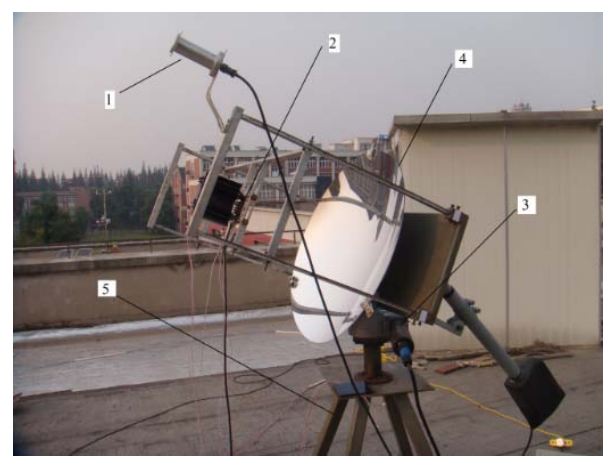

1. sun tracker; 2. solar module; 3. transmission mechanism; 4. concentrator; 5. stent

Fig. 1 Dish-Style Concentrating Photovoltaic System

Photovoltaic cell is the key component of the photovoltaic system, the electrical characteristics of which have a direct impact on the performance of the system. InGaP/InGaAs/Ge triple-junction photovoltaic cell is used in this paper, which has a lot of advantages such as big optical absorption coefficient, low temperature coefficient and high photoelectric conversion efficiency. The InGaP/InGaAs/Ge triple-junction photovoltaic cell used in this paper is shown in Fig.2. The area of the cell chip is $5 \times 5 \mathrm{~mm}$. The bottom of the cell is made up of high thermal conductivity material. Positive and negative electrodes are below the cell, which are used to connect related electrical parameter measuring equipment. The bypass diode is between the positive and negative electrodes, which is used to protect solar cell from being damaged due to some of them lacking of light for the occlusion under high light. There is a homogenizer over the cell, the function of which is uniforming the spots reflected from the concentration to the surface of the cell and eliminating the bad influence on the photovoltaic cell due to the deviation of the incident angle. It will help to improve the efficiency of solar cell. 


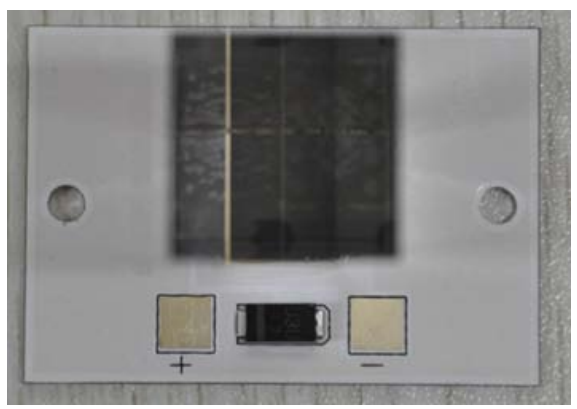

Fig.2 InGaP/InGaAs/Ge triple-junction photovoltaic cell

\section{Measuring equipment}

The dish-style concentrating photovoltaic system established in this paper is shown in Fig.3. Temperature in the photovoltaic system includes photovoltaic cell temperature and fin type heat pipe radiator temperature. Temperature data are measured by T-type thermocouple and recorded by Agilent 34970A. Electrical parameters include open circuit voltage $\mathrm{V}_{\mathrm{oc}}(\mathrm{V})$, short circuit current $\mathrm{I}_{\mathrm{sc}}(\mathrm{A})$, peak power $\mathrm{P}_{\mathrm{mm}}(\mathrm{W})$ and conversion efficiency $\eta(\%)$. Measurement data are recorded automatically by the $\mathrm{I}-\mathrm{V}$ recorder. Meteorological parameters include local wind speed $(\mathrm{m} / \mathrm{s})$, local temperature $\left({ }^{\circ} \mathrm{C}\right)$, local relative humidity $(\%)$, solar total radiation intensity $\mathrm{E}_{\mathrm{t}}\left(\mathrm{W} / \mathrm{m}^{2}\right)$ and direct solar radiation intensity $\mathrm{E}_{\mathrm{d}}\left(\mathrm{W} / \mathrm{m}^{2}\right)$. The data are recorded automatically by a meteorological parameters recorder. All the data above are recorded by the program itself on the computer.

The influence of the electrical characteristics of photovoltaic cell under different concentrating ratio, direct solar radiation intensity and environment conditions has been measured by using this experimental device. The concentration ratio, which is actual concentration ratio in this paper, can be defined as the ratio of the short-circuit current after concentrating and the short-circuit current of photovoltaic cell under 1time sunlight, which is more close to the actual situation and can reflect the actual electrical characteristics of photovoltaic cell.

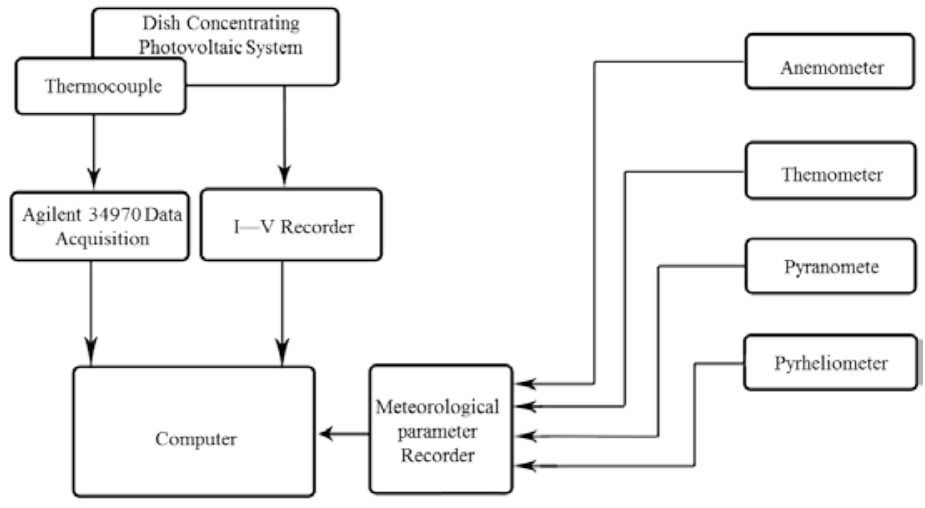

Fig.3 Dish Concentrating Photovoltaic System Performance Test Platform

4. Results and Discussion

Assuming that the short circuit current is proportional to the incident radiation flux, the concentration ratio of the dish-style concentrating photovoltaic system is expressed as:

$$
C=\frac{I_{s c x}}{I_{s c}}
$$


There is only one concentrating cell and the spot area after focusing is bigger than the area of the InGaP/InGaAs/Ge triple-junction photovoltaic cell. Therefore, efficiency calculated is the efficiency of the power per unit area, which is:

$$
\eta_{c}=\frac{P_{m p}}{C \times E_{d} \times A_{c} \times \eta_{r}}
$$

Fill factor can be defined as:

$$
F F=\frac{V_{m p} \times I_{m p}}{V_{o c} \times I_{s c x}}
$$

The peak power is:

$$
P_{m p}=V_{m p} \times I_{m p}=V_{o c} \times I_{s c x} \times F F
$$

The experimental results of the dish-style concentrating photovoltaic system on November 27, 2010 are shown in Fig.6 Fig.8.

The $I_{s c}$ of the InGaP/InGaAs/Ge triple-junction photovoltaic cell changing with the cell temperature from 8:00 16:00 is shown in Fig.7. The change of $I_{S c}$ is the same with the change of cell temperature, which is contrary to $V_{o c}$. The $I_{s c}$ is smaller in the morning and afternoon, which are respectively $0.589 \mathrm{~A}$ and $0.323 \mathrm{~A}$. At the same time , the cell temperature are respectively $49.9^{\circ} \mathrm{C}$ and $55.6^{\circ} \mathrm{C}$. When cell temperature reaches the peak value of $69.9^{\circ} \mathrm{C}$, the $I_{s c}$ of the photovoltaic cell reaches a minimum value of $0.694 \mathrm{~A}$. The $I_{S C}$ of the photovoltaic cell gets bigger with the rise of the cell temperature. Visibly, cell temperature also has an important effect on the $I_{s c}$ of the InGaP/InGaAs/Ge concentrating photovoltaic cell.

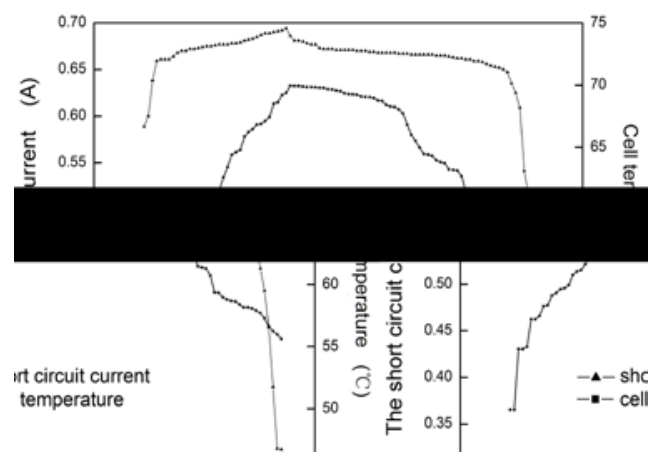

Fig.4 The relation between $I_{s c}$ and cell temperature

The power density of the InGaP/InGaAs/Ge triple-junction photovoltaic cell changing with the cell temperature from 8:00 16:00 is shown in Fig.8. At 8:00 in the morning, when the cell temperature is $49.9^{\circ} \mathrm{C}$, the power density of the cell is $2.172 \mathrm{~W} / \mathrm{cm}^{2}$. And then with the increase of radiation intensity, the power density decreases. The cell temperature reaches the peak value of $69.9^{\circ} \mathrm{C}$ at 11:00 and at the same time the power density of the cell is $1.94 \mathrm{~W} / \mathrm{cm}^{2}$. And then with the decline of the cell temperature, the power density increases. When the cell temperature reaches $59.3^{\circ} \mathrm{C}$ at $14: 30$, the power density is $2.1148 \mathrm{~W} / \mathrm{cm}^{2}$. After that, with the decline of the cell temperature, the power density gradually decreases. When the cell temperature reaches $55.6^{\circ} \mathrm{C}$ at $16: 00$, the power density is $1.904 \mathrm{~W} / \mathrm{cm}^{2}$. 


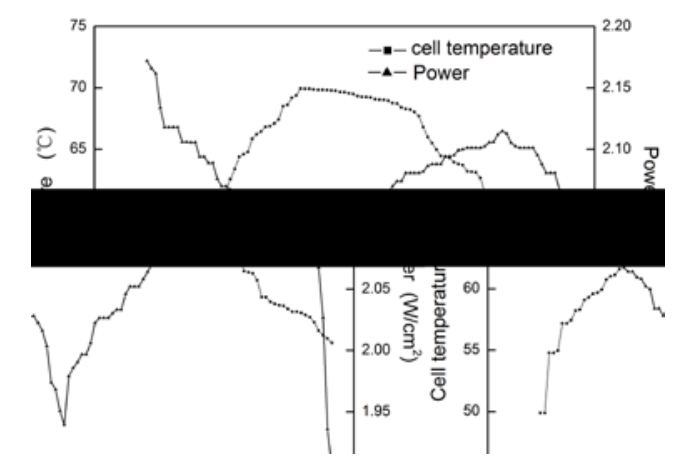

Fig. 4 The relation between power density and cell temperature

The cell efficiency of the InGaP/InGaAs/Ge triple-junction photovoltaic cell changing with cell temperature from 8:00 16:00 is shown in Fig.9, which is the same with the variation of the cell peak power. At 8:00 in the morning, when the cell temperature is $49.9^{\circ} \mathrm{C}$, the cell efficiency is $31.19 \%$.And then with the increase of the cell temperature, the cell efficiency decreases. The cell temperature reaches the peak value of $69.9^{\circ} \mathrm{C}$ at $11: 00$ and at the same time the cell efficiency is $19.05 \%$. And then with the decline of the cell temperature, the cell efficiency increases. When the cell temperature reaches $59.3^{\circ} \mathrm{C}$ at $14: 30$, the cell efficiency is $34.55 \%$. After that, with the decline of the cell temperature, the cell efficiency gradually decreases. When the cell temperature reaches $55.6^{\circ} \mathrm{C}$ at $16: 00$, the cell efficiency is $27.54 \%$.

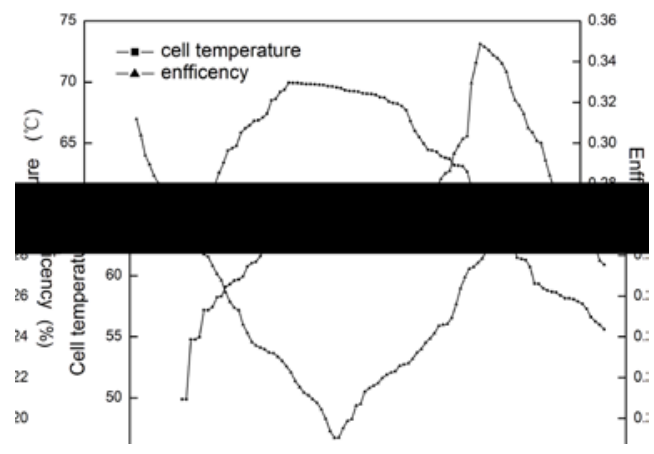

Fig. 6 The relation between cell efficiency and cell temperature

\section{Conclusions}

Researches on electrical characteristics of the InGaP/InGaAs/Ge triple-junction solar cell had been done based on the dish-style concentrating photovoltaic system established in this paper. According to the experimental results, the following conclusions can be got. The changing trend of peak power of the photovoltaic cell is not totally different with that of the direct solar radiation intensity. They can reach maximum in the morning and at 14:30. When the concentrating ratio is 200X, the average direct solar radiation intensity is $600 \mathrm{~W} / \mathrm{m}^{2}$ and environmental average temperature is $28.9^{\circ} \mathrm{C}$, the average open-circuit voltage, short-circuit current, power density, cell efficiency and cell temperature are respectively $2.72 \mathrm{~V}, 0.65 \mathrm{~A}, 2.07 \mathrm{~W} / \mathrm{cm}^{2}, 26 \%$ and $63.51{ }^{\circ} \mathrm{C}$. Compared with fixed non-concentrating photovoltaic system, some measures like automatically tracking sun and natural cooling can benefit the InGaP/InGaAs/Ge triple-junction photovoltaic cell under high concentration. And the system can get more generating capacity under the same solar cell area. It is equivalent to use mirror or some other cheap equipments instead of expensive 
crystalline silicon photovoltaic cells. It reduces the cost of photovoltaic power generation, which has an important meaning on widely promoting solar photovoltaic power generation, especially the high concentrating photovoltaic system.

6. Acknowledgments

This work was supported by the National Natural Science Foundation of China (51606126) and Natural Science Foundation of Shanghai (15ZR1428800)

\section{Reference:}

[1] SWANSON R M. The promise of concentrators [J]. Research and applications,2000,8(1):93 111

[2] Wang Sicheng. Review and trend of solar photovoltaic technology [J]. International Power, 2006, (4): 21 23.

[3] ANDREEV V M, et al. Concentrator PV modules and solar cells for TPV systems[J]. Solar Energy Material \& Solar Cells, 2004, (84): 3 17.

[4] LETAY G, BETT A W. EtaOpt-a program for calculating limiting efficiency and optimum band gap structure for multi-band gap solar cells and TPV cells[C]. 17th European Photovoltaic Solar Energy Conference, Munich, 2002

[5] M HEIN, et al. Characterisation of a 300X photovoltaic concentrator system with one-axis tracking[J]. Solar Energy Materials \& Solar Cells, 2003, 75(1): 277 283.

[6] Y KEMMKOU, et al. Modeling of module temperature of a concentrator PV system[C]. 19th European Photovoltaic Solar Energy Conference, Paris, 2004, 2568-2571.

[7] XU Yongfeng, LI Ming, et al. The effect of concentrated light intensity on output performance of solar cell arrays[J]. Acta Physica Sinica, 2009, 58(11): 8067 8076.

[8] XU Zhilong, LIU Judong, FENG Peifeng, HOU Dapan, ZHANG Jianyi, ZHANG Yaoming. Research on a butterfly concentrator for photovoltaic generation[J]. Acta Energiae Solaris Sinica, 2007, 28(2): 174 177.

[9] DU Bin, ZHANG Yaoming, SUN Liguo. Experimental investigation of a low concentrating photovoltaic system[J]. Acta Energiae Solaris Sinica, 2008, 29(11): 1328 1332.

[10] ZHANG Haiyan, ZHANG Chongwei, WANG Jianping. Study of the harmonic control method to obtain the max irradiation of solar energy photovoltmc system in multi-glass focusing solar radiation[J]. Acta Energiae Solaris Sinica, 2008, 29(11): 1138 1142. 